\title{
AN IMMUNOHISTOCHEMICAL STUDY OF CYCLOOXYGENASE-2 EXPRESSION IN CANINE MULTICENTRIC LYMPHOMA
}

\author{
Immunoreactivity of COX-2 in nomal lymph node and lymphoma in dogs.
}

\author{
Rodrigues, L.C.S. ${ }^{1}$, Cogliati, B. ${ }^{2}$, Guerra, J.L. ${ }^{2}$, Dagli, M.L.Z. ${ }^{2}$, Lucas, S.R.R.*1 \\ ${ }^{1}$ Departamento de Clínica Médica, Faculdade de Medicina Veterinária e Zootecnia (FMVZ), \\ Universidade de São Paulo (USP), Av. Prof. Dr. Orlando Marques de Paiva, 87, São Paulo, SP - \\ 05508-900, Brasil. and ²Departamento de Patologia, FMVZ-USP, São Paulo, SP, Brasil.
}

*Autor para correspondencia: Sílvia Regina Ricci Lucas. Tel.: + 5511 30911338; Fax: + 5511 30911338,E-mail: srrlucas@usp.br

\begin{abstract}
Cyclooxygenase-2 (COX-2) expression has been associated with development and progression in spontaneous human and dogs tumors. Studies demonstrated that non-steroidal anti-inflammatory drugs, which inhibit COX enzyme, may be used in the treatment of some tumors. Lymphoma is a systemic disease and the most common hematological malignancy in dogs. There are few studies about COX-2 expression in human and canine lymphoma. In this study, immunohistochemical evaluation for COX-2 expression was performed in 12 dogs with multicentric lymphoma. The diagnosis was confirmed by histopathological examination. Six samples of normal lymph nodes were either used in the study. No COX-2 immunoreactivity was detected in all samples from canine lymphoma and normal lymph nodes, as well previous studies in canine lymphoma.
\end{abstract}

Key words: cancer, dogs, immunohistochemistry, COX-2, lymphoma.

\section{RESUMEN}

La expresión de la ciclooxigenasa-2 (COX-2) se ha asociado con el desarrollo y progresión de tumores espontáneos humana y canina. Los estudios han demostrado que los antiinflamatorios no esteroideos, inhibidores de la COX-2 pueden ser utilizados para tratar algunos tumores. El linfoma es una enfermedad sistémica, considerada la neoplasia hematopoyética más frecuente en los perros. Hay pocos estudios sobre la expresión de la COX-2 en los linfomas en los seres humanos y perros. En este estudio, la expresión de COX-2 fue evaluada por inmunohistoquímica en 12 perros con linfoma multicéntrico. El diagnóstico fue confirmado por histopatología. Seis muestras de los ganglios linfáticos normales fueron evaluadas también. En ninguna de las muestras de los ganglios linfáticos normales o neoplásicos se detectó la expresión de la COX-2, corroborando los resultados de estudios previos en el linfoma canino.

Palabras clave: cáncer, perros, inmunohistoquímica, COX-2, linfoma. 


\section{INTRODUCTION}

Lymphomas are the most common hematopoietic neoplasms in the $\operatorname{dog}$ and represent an abnormal proliferation of lymphocytes. Etiologic factors such as infection, genetic disorders, chemical agents and immunodeficiency are reported and associated with the etiopathogenesis of the disease. The multicentric form represents $80-85 \%$ of cases and it is characterized by generalized painless lymphadenopathy, but nonspecific signs such as anorexia, vomiting, diarrhea, weight loss, ascite, dyspnea, polyuria, polydypsia and fever are often present (Withrow and Vail 2007).

Canine lymphoma is a systemic disease, similar to non-Hodgkin's lymphoma (NHL) in human beings. It is a chemo-responsive neoplasm and complete remission rates are high when dogs are treated with chemotherapy. Eighty to eighty five percent of dogs with multicentric lymphoma achieve complete or partial remission receiving treatment protocols based on CHOP: cyclophosphamide, doxorubicin, vincristine and prednisone (Withrow and Vail 2007). Dogs undergoing chemotherapy maintain a good quality of life, and the treatment can provide resolution of many signs and abnormalities. Despite advances in chemotherapy, few dogs are cured. Survival time and therapy responses could vary greatly among animals.

Over the past 30 years many experimental and clinical studies have associated tumor development and progression with the presence of cyclooxygenase (COX) in human tumors, mainly cyclooxygenase 2. Cyclooxygenase enzymes catalyze the conversion of arachidonic acid to prostaglandins and there are two distinct isoenzymes: cyclooxygenase-1 (COX-1) and 2 (COX-2). They are involved with prostaglandin synthetase complex which plays a role in the production of prostaglandins from arachidonic acid (Millanta 2006). Arachidonic acid is a 20 carbon unsaturated fatty acid distributed throughout the lipid bilayer of the cell (Williams et al. 1999).COX-1 is expressed constitutively in many cells and is involved in normal physiologic activities such as cytoprotection of the gastric mucosa, platelet aggregation and regulation of renal blood flow. COX-2 is induced rapidly in response to growth factors, tumor promoters, hormones, bacterial endotoxin, cytokines and shear stress (Appleby et al. 1994). As soon, it's seems to be involved in the processes of malignant transformation and tumor progression by affecting cell proliferation, mitosis, cell adhesion, apoptosis, immune-surveillance, and angiogenesis (Williams et al. 1999).

In the last years, studies have demonstrated that non-steroidal anti-inflammatory drugs (NSAID), which inhibit COX enzymes, can reduce the incidence and mortality rates of cancer in humans and animals (Knapp et al. 1994, Khan et al. 2001). NSAIDs are responsible to blockage of prostaglandin production through the inhibition of cyclooxygenases. Prostaglandins have been incriminated to participate in resistance to apoptosis process and angiogenesis (Gately 2000, Dempke et al. 2001). COX-2 contributes to tumor angiogenesis increasing expression of the proangiogenic growth factor VEGF and producing eicosanoid products such as tromboxane $\mathrm{A}_{2}$, $\mathrm{PGE}_{2}$, and $\mathrm{PGI}_{2}$, that can directly stimulate endothelial cells migration (Gately 2000). Consequently, NSAID have antiangiogeneic and proapoptotic effects and could be used to treat cancer in combination to chemotherapy (Hazar et al. 2003).

In human and dogs different studies showed COX-2 expression in a variety of cancers, and in both species, solid tumors have high expression of this enzyme. Using immunohistochemistry evaluation, COX-2 were detect in sections of canine primary tumors in particular in transition cells carcinoma, prostatic carcinoma, squamous cells carcinomas, nasal carcinomas, mammary tumors and malignant melanoma (Tremblay et al. 1999, Khan et al. 2001, Mohammed et al., 2001, Pestile et al. 2001, Dore et al. 2003, 
Millanta et al. 2006, Queiroga et al. 2007, Impellizeri and Esplin 2008; Pires et al., 2010). These studies contribute to the identification of potential targets for anti-COX-2 therapy adjuvant with chemotherapy standard protocols, but there are few studies reporting COX-2 expression in hematopoietic tumors in veterinary medicine. COX-2 is expressed in human non-Hodgkin's lymphoma (Hazar et al. 2004, Paydas et al. 2007), that have similarity with canine lymphoma. Considering these facts, we performed this study to evaluate $\mathrm{COX}-2$ expression by immunohistochemistry, in canine multicentric lymphoma.

\section{MATERIALS AND METHODS}

\section{Animals}

COX-2 expression was evaluated in normal lymph nodes from 6 dogs. These lymph node samples were obtained from dogs that had natural causes of death for non-cancer reasons, at University of São Paulo Veterinary Teaching Hospital, without lymph node abnormalities, comproved by histopathologycal examination.

COX-2 expression evaluation was also performed in 12 client-owned dogs with multicentric lymphoma that were referred to University of Sao Paulo Veterinary Teaching Hospital. Diagnosis was confirmed by histopathological analysis of hematoxylin and eosin-stained sections of samples fixed in $10 \%$ buffered formalin, embedded in paraffin wax and sectioned at $5 \mu \mathrm{m}$ (Leica RM2255, Germany). The dogs were in stage III, IV or V of disease. All dogs were free of complicating concurrent disease and had not received any previous treatment, including the use of corticosteroids. The immunphenotyping was performed using CD3 (Dako, USA, catalogue number A0452, dilution 1:100, polyclonal) and CD79a markers (Dako, USA, catalogue number M7050, dilution 1:100, monoclonal). After diagnosis and staging, all dogs received chemotherapy treatment.

\section{COX-2 Immunohistochemistry}

The slides were deparaffinized in xylene and hydrated in descending alcohols. For antigen exposure, the tissues sections were heat treated for 3.5 minutes with citrate buffer $(10 \mathrm{mM}, \mathrm{pH}$ 6.0 ) in a pressure cooker (Eterna ${ }^{\circledR}$, Nigro). Endogenous peroxidase activitiy was inhibited with hydrogen peroxide in water solution $6 \%$ (Merck) for 30 minutes in the dark. After that, the tissue sections were washed with PBS (10 $\mathrm{mM}, \mathrm{pH}$ 7.2) followed by overnight incubation, in a moist chamber, at $4^{\circ} \mathrm{C}$, with polyclonal anti-rabbit (COX-2) antibody (Cell Signaling \#4842, dilution 1:50). The slides were incubate with SuperPicture Poly HRP conjugate (Zymed, USA, $n^{\circ}$. 87-8963) for 30 minutes at $37^{\circ} \mathrm{C}$. For detection, the slides were incubated with diaminobenzidine (DAB, Sigma, USA, D-5637) for 5 minutes at $37^{\circ} \mathrm{C}$ and were counterstained with Harris Hematoxilina, dehydrated with ethanol and converslipped with mounting medium (Knittel, StarFrost, Germany). Canine mammary carcinoma tumors showing high COX-2 expression, predominantly cytoplasmatic (Fig. 1A) were used as a positive control in the same reaction. Cytoplasmatic staining is considered as a positive result and the staining intensity is scored on a scale of 0-3, where 0 is no staining and 3 is strong staining. Negative controls were performed by replacing primary antibodies with PBS.

\section{RESULTS}

\section{Characteristics of dogs with multicentric lymphoma}

There were four male and eight female, nine were pure bred and three mongrel dogs. The mean age was 5.5 years (range 3-7 years). One dog was in stage III, two dogs in stage IV and nine were in stage V. According Working Formulation, one dog had lymphoblastic lymphoma, three had immunoblastic large cell 
lymphoma, three had diffuse non cleaved large cells lymphoma, one had diffuse cleaved large cells lymphoma, two had diffuse lymphoma, mixed lymphoma, small and large cleaved cells lymphoma, one had diffuse small cells lymphoma and one had small lymphocytic cells lymphoma. One dog was immunophenotype B and 11 presented $\mathrm{T}$ cell lymphoma.

\section{Immunohistochemistry for COX-2}

To determine if COX-2 was expressed under normal conditions, immunohistochemical staining was performed on normal canine lymph node. Six samples were evaluated, and COX2 was negative in all cases (Fig. 1B). Only a few macrophages were $\mathrm{COX}-2$ positive in the lymph nodes. Immunostaining of multicentric canine lymphoma tissue revealed that all samples $(n=12)$ were also COX-2 negative (Fig. 1C). However, in 4 samples, weak COX-2 was seen localized to the nucleus of tumors cells (Fig. 1D).

\section{DISCUSSION}

The mechanism by which COX-2 is up regulated in cancer is not clear. It has been suggested that cancer cell may become intrinsically more active in expressing COX2 than the normal cells. In humans, COX-2 expression is associated with poor prognosis, thus, several studies have been performed to identify COX-2 in solid tumors in humans and animals but there is few reports concerning cyclooxygenase expression and hematological malignancies.

In human beings, Hazar et al. (2004), showed COX-2 expression in 70\% (7/10) of patients with Hodgkin's disease and 57\% (24/42) of patients with NHL, similar to Paydas et al. (2007), that found 56\% (99/177) positivity in NHL, both using immunohistochemical technique. Hazar and others (2004) showed that lymphoma patients with COX-2 expression had low response to therapy and it was associated with poor prognosis. Considering the similarities between the lymphoma in dogs and human beings, the same could occur in dogs, but COX-2 expression was not detected in canine lymphoma in this study, as had been observed in a previous study of Mohammed et al. (2004).

These authors evaluated COX-1 and COX-2 expression in several types of naturally-occurring tumors in dogs. COX-2 highly expressed was detected in epithelial tumors, while it was infrequently detected in mesenchymal tumors and was absent in canine lymphoma (10 animals were studied). In that report, the authors also studied nine samples of normal lymph node and did not observe positivity for COX-2. In our study, the results agree with Mohammed et al. (2004), since COX-2 expression was not detected in lymphoma tissue and normal lymph node.

In four samples of canine lymphoma a weak nuclear staining for COX-2 were identified. Due to the fact that nuclear staining is unexpected localization for COX-2 in lymphoma cell, this label could be associated with nonspecific staining of the antibody or may be a feature of canine lymphoma. Although in human lymphoma just a cytoplasmatic localization of COX-2 is related in some articles (Li et al., 2004; Szczurasek et al., 2010) in other canine tumors like mammary tumor (Queiroga et al., 2007), intestinal tumor (McEntee et al., 2002) and oral malignant melanoma (Pires et al., 2010), nuclear or a perinuclear immunolabelling were detected in some tumor samples. If a large study could be carried out, this fact would be elucidated.

In many others canine tumors, which high expression of COX-2 can be observed, NSAID treatment improves clinical response. In canine inflammatory mammary tumors, for example, COX-2 is highly expressed in all samples, and the treatment with piroxicam improve quality of life and increases survival rate when compared 

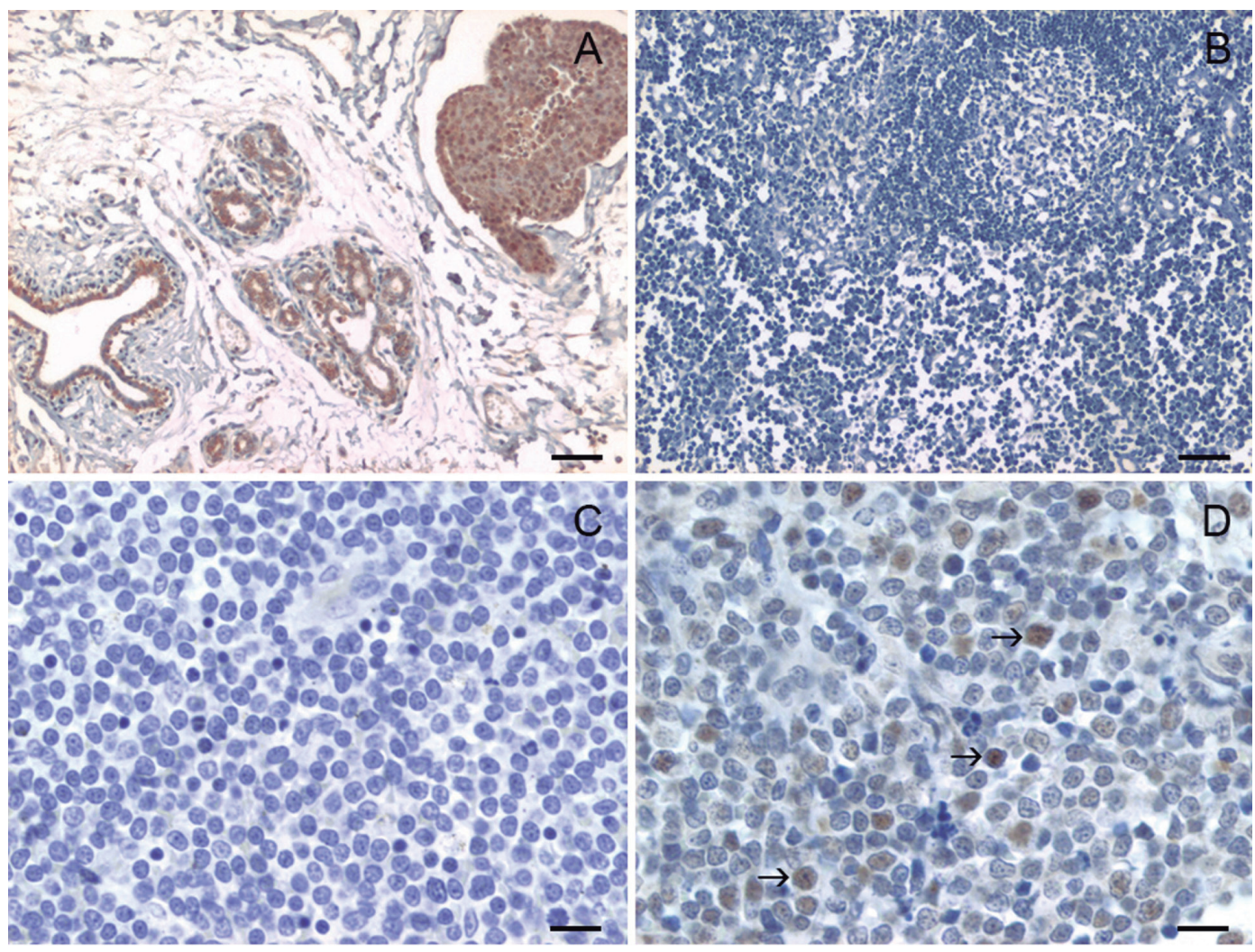

Figure 1: Immunohistochemistry for COX-2. (A) Canine mammary carcinoma tumor as positive control of reaction, with strong staining in epithelial and tumoral cells. Bar $=100 \mathrm{~mm}$. (B) Normal canine lymph node without expression of COX-2. Bar $=40 \mathrm{~mm}$. (C) Immunostaining of multicentric canine lymphoma demonstrating no expression of COX-2 in neoplasic cells. Bar = $10 \mathrm{~mm}$. (D) Pattern of nonspecific nuclear immunostaning in some neoplasic cells (arrows). Bar $=10 \mathrm{~mm}$.

with dogs treated with doxorubicin as a single agent (De M Souza et al. 2009).

In canine multicentric lymphoma Mutsaers and others (2002) evaluated the antitumors effect of a treatment using doxorubicin combined with piroxicam and doxorubicin as a single drug. The percentages of dogs that had remission with doxorubicin-piroxicam treatment (79\%) or doxorubicin treatment (74\%) were not significantly different, as well as the results of remission duration or survival time. Although the authors recognize some limitations in the groups studied, the absence of COX-2 expression, as observed in this study and the lower PGE2 concentration observed in lymphoma tissue (Mohammed et al. 2001) could explain the lack of beneficial effects of NSAID in the treatment of lymphoma.

In conclusion, the association of COX2 inhibitor with chemotherapy protocols for multicentric lymphoma probably did not bring benefits for dogs, by the fact that this and other studies did not detect COX-2 expression in canine lymphoma tissue. 


\section{REFERENCES}

APPLEBY S.B., RISTIMAKI A., NEILSON K., NARKO K. \& HLA T. 1994. Structure of the human cyclooxygenase-2 gene. Biochem. J. 302:723-727.

De M SOUZA C.H., TOLEDO-PIZA E., AMORIN R., BARBOZA A. \& TOBIAS K.M.

2009. Inflammatory mammary carcinoma in 12 dogs: clinical features, cyclooxygenase-2 expression, and response to piroxicam treatment. Can. Vet. J. 50: 506-510.

DEMPKE W., RIE C., GROTHEY A. \& SCHOMOLL H.J. 2001. Cyclooxygenase-2: a novel target for cancer chemotherapy? J. Cancer Res. Clin. Oncol. 127: 411-417.

DORE M., LANTHIER I. \& SIROIS J. 2003. Cyclooxygenase-2 expression in canine mammary tumors. Vet. Pathol. 40: 207-212.

GATELY S. 2000. The contributions of cyclooxygenase-2 to tumor angiogenesis. Cancer Metastasis Rev. 19: 19-27.

HAZAR B., PAYDAS S., ZORLUDEMIR S., SAHIN B. \& TUNCER I. 2003. Prognostic significance of microvessel density and vascular endothelial growth factor (VEGF) expression in non-Hodgkin's lymphoma. Leuk. Lymphoma 44: 2089-2093.

HAZAR B., ERGIN M., SEYREK E., ERDOGAN S., TUNCER I. \& HAKVERDI S. 2004. Cyclooxygenase-2 (Cox-2) expression in lymphomas. Leuk. Lymphoma 45: 1395-1399.

IMPELLIZERI J.A. \& ESPLIN D.G. 2008. Expression of cyclooxygenase-2 in canine nasal carcinomas. Vet.J. 176: 408-410.

KHAN K.N.M., STANFIELD K.M., TRAJKOVIC D. \& KNAPP D.W. 2001. Expression of

cyclooxygenase-2 in canine renal cell carcinoma. Vet. Pathol. 38: 116-119.

KNAPP D.W., RICHARDSON R.C., CHAN T.C., BOTTOMS G.D., WIDMER W.R., DeNICOLA D.B., TECLAW R., BONNEY
P.L. \& KUCZEK T. 1994. Piroxicam therapy in 34 dogs with transitional cell carcinoma of the urinary bladder. J. Vet. Intern. Med.8: 273-278.

LI H.L., SUN B.Z., MA F.C. 2004. Expression of COX-2, iNOS, p53, and ki-67 in gastric mucosa-associated lymphoid tissue lymphoma. World J. Gastroenterol. 10: 1862:1866.

MCENTEE M.F., CATES J.M., NEILSEN N. 2002. Cyclooxigenase-2 expression in spontaneous intestinal neoplasia of domestic dogs. Vet. Pathol. 39: 428-436.

MILLANTA F., CITI S., DELLA SANTA D., PORCIANI M. \& POLI A. 2006. COX-2 expression in canine and feline invasive mammary carcinomas: correlation with clinicopathological features and prognostic molecular markers. Breast Cancer Res. Treat. 98: 115-120.

MOHAMMED S.I., COFFMAN K., GLICKMANN.W.,HAYEK M.G.,WATERS D.J., SCHLITTER D., DeNICOLA D.B. \& KNAPP D.W. 2001. Prostaglandin $\mathrm{E}_{2}$ concentration in naturally occurring canine cancer. Prostaglandins Leukot. Essent. Fatty Acids 64:1-4.

MOHAMMED S.I., KHAN K.N.M., SELLERS R.S., HAYEK M.G., DeNICOLA D.B., WU L., BONNEY P.L \& KNAPP D.W. 2004. Expression of cyclooxygenase-1 and 2 in naturally-occurring canine cancer. Prostaglandins Leukot. Essent. Fatty Acids 70: 479-48.

MUTSAERS A.J., CLICKMAN N.W., DeNICOLA D.B., WINMWE W.R., BONNEY P.L., HAHN K.A. \& KNAPP D.W. 2002. Evaluation of the treatment with doxorubicin and piroxicam or doxorubicin alone for multicentric lymphoma in dogs. J. Am. Vet. Assoc. 220: 1813-1817.

PAYDAS S., ERGIN M., ERDOGAN S. \& SEYDAOGLU G. 2007. Cyclooxygenase-2 expression in non-Hodgkin's lymphomas. Leuk. Lymphoma 48: 389-395. 
PESTILE de ALMEIDA E.M., PICHE C., SIROIS J. \& DORE M. 2001. Expression of cyclo-oxygenase-2 in naturally occurring squamous cell carcinomas in dogs. J. Histochem. Cytochem. 49: 867-875.

PIRES I., GARCIAA., PRADA J., QUEIROGA F.L. 2010. COX-1 and COX-2 expression in canine cutaneous, oral and ocular melanocytic tumours. J. Comp. Pathol. 143:142-149.

QUEIROGA F.L., ALVES A., PIRES I. \& LOPES C. 2007. Expression of Cox-1 and Cox-2 in canine mammary tumours. J. Comp. Pathol. 136:177-185.

SZCZURASZEK K., MATERNA V., HALON A., MAZUR G., WROBEL T., KULICZKOWSKI K., MACIEJCZYK A., ZABEL M., DRAG M., DIETEL M.,
LAGE H., SUROWIAK P. 2009. Positive correlation between cyclooxygenase-2 and $\mathrm{ABC}$-transporter expression in nonHodgkin's lymphomas. Oncol Rep. 22: 1315-1323.

TREMBLAY C.,DORÉM.,BOCHSLER P.N.\& SIROIS J. 1999. Induction of prostaglandin $\mathrm{G} / \mathrm{H}$ synthase-2 in a canine model of spontaneous prostatic adenocarcinoma. J. Natl. Cancer Institute 91: 1398-1403.

WILLIAMS C.S., MANN M. \& DUBOIS R.N. 1999. The role of cyclooxygenases in inflammation, cancer, and development. Oncogene 18: 7908-7916.

WITHROW S.J. \& VAIL D.M. Withrow and MacEwen's Small Animal Clinical Oncology, 4th ed., Missouri: Saunders Elsevier, 2007: 699-733. 
